\section{U.S. DEPARTMENT OF ENERCY}

\section{Office of}

ENERGY EFFICIENCY \& RENEWABLE ENERGY

\title{
Federal Workplace Charging Program Guide
}

November 2020 
(This page intentionally left blank) 


\section{Acknowledgments}

This report was developed for and sponsored by the U.S. Department of Energy's Federal Energy Management Program (FEMP) with Kendall Kam as the program manager. Additional FEMP reviewers include Jay Wrobel and Karen Guerra.

This report was authored by Jesse Bennett and Cabell Hodge of the National Renewable Energy Laboratory (NREL). NREL reviewers also include Ted Sears, Margo Melendez, and Sheila Hayter.

Stephanie Gresalfi, Casey Crandell, and Sharon Conger with the U.S. General Services Administration provided invaluable input to a draft of this document. Ron Stewart with the Idaho National Laboratory offered his expertise regarding reporting requirements. Matt Bianco with FedWay Consulting graciously shared several examples with the document preparation team. Best practices and policies from the U.S. Navy, Marine Corps, Army, Air Force, National Aeronautics and Space Administration, Federal Bureau of Investigation, U.S. Department of Energy, and U.S. Postal Service informed this program guide as well. The authors would like to thank their colleagues at all of these agencies as well as Heidi Blakley and Caitlin Dorsey for their meticulous attention to detail reviewing this report. 


\section{List of Acronyms}

$\begin{array}{ll}\text { BPA } & \text { blanket purchase agreement } \\ \text { DCFC } & \text { Direct current fast charger } \\ \text { DOE } & \text { U.S. Department of Energy } \\ \text { EVSE } & \text { electric vehicle supply equipment } \\ \text { FAST } & \text { Federal Automotive Statistical Tool } \\ \text { FAST Act } & \text { Fixing America's Surface Transportation Act } \\ \text { FEMP } & \text { Federal Energy Management Program } \\ \text { GSA } & \text { U.S. General Services Administration } \\ \text { NREL } & \text { National Renewable Energy Laboratory } \\ \text { P100 } & \text { PBS Building Standards } \\ \text { PEV } & \text { plug-in electric vehicle } \\ \text { POV } & \text { privately owned vehicle }\end{array}$




\section{Executive Summary}

The Fixing America's Surface Transportation (FAST) Act authorizes the installation, operation, and maintenance of electric vehicle supply equipment (EVSE) for the purpose of recharging privately owned vehicles (POVs) under the custody or control of the General Services Administration or the Federal agency. It requires the collection of fees to recover the costs of installing, operating, and maintaining this equipment and imposes reporting requirements. This model program guide reviews those requirements, excerpts the relevant language in Appendix A, and describes when and how fees may be required to cover costs of electricity, network costs, EVSE units, and installations in various scenarios.

This model program guide is designed to support federal agencies developing and refining workplace charging programs for employee POVs. It contains a roadmap for agency workplace charging programs and defines roles and responsibilities. For example, it recommends establishing a national project leader, a regional coordinator if appropriate, and a facility coordinator at each location where EVSE is provided for POV use. Identifying persons for these roles may help ensure a uniform approach and compliance with the relevant requirements. The guide explains how to determine the number of POVs likely to charge at a given site and contains a model employee survey in Appendix B. It reviews EVSE planning, including unit selection and acquisition, charger location(s), accounting for available power capacity, using existing infrastructure, and funding an incentive program. The guide also discusses the costs associated with EVSE acquisition, installation, and network management. These costs inform the subsequently provided information, which describes how to amortize costs over time to determine appropriate fees for each charging session. Appendix $\mathrm{C}$ contains calculations that can be used to determine session fees for any federal facility. The final two sections of this guide address aspects of ongoing program management that the facility coordinator should consider, and the reporting requirements associated with the FAST Act.

The insights in this guide are applicable to all agency-owned and GSA-leased buildings or facilities offering the use of EVSE or a 120-volt receptacle for the purpose of recharging a POV. However, the FAST Act requirements typically do not apply to any building or facility operated and maintained by a third-party vendor offering the use of EVSE as part of a commercial building lease. 


\section{Table of Contents}

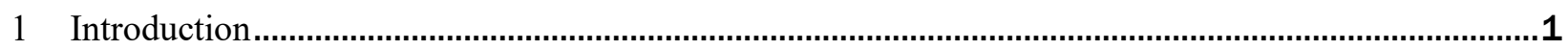

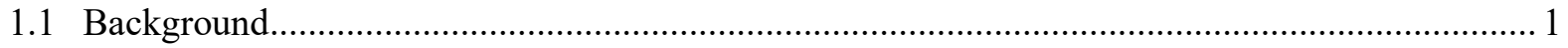

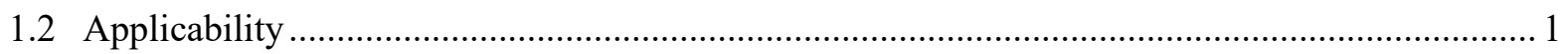

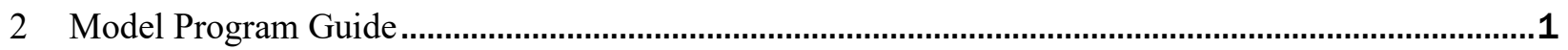

2.1 Roles and Responsibilities.......................................................................................

2.2 Employee Survey .................................................................................................

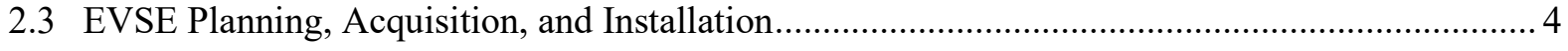

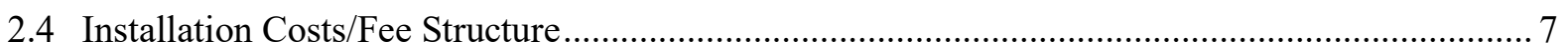

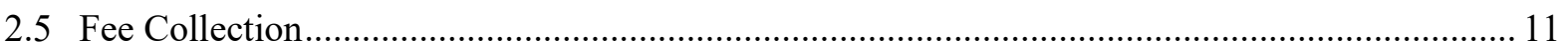

2.6 Program Management...................................................................................................... 12

2.7 Reporting 12

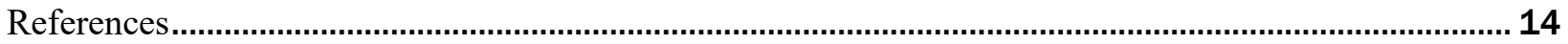

Appendix A: 42 U.S.C. $§ 6364$. Operation of battery recharging stations in parking areas used by Federal

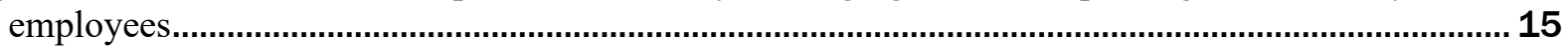

Appendix B: Template for Employee Survey …………………..................................................... 18

Appendix C: POV Fee Calculations....................................................................................................... 19

\section{List of Figures}

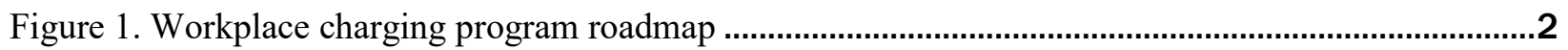

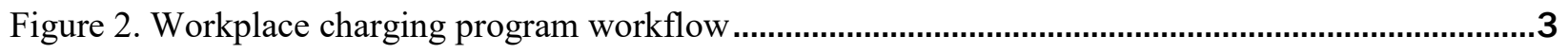

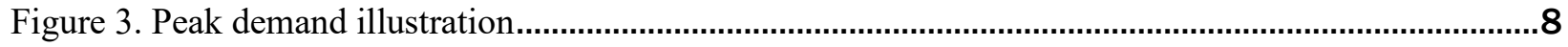

\section{List of Tables}

Table 1. Vehicle Charging Rates Based on Data From 2019 Sales ..............................................................5

Table 2. Vehicle Energy Needs and Charge Session Duration ..................................................................5

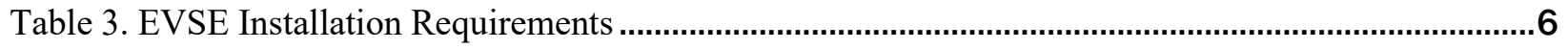

Table 4. Estimated Electricity Cost per Charging Session ...........................................................................

Table 5. Example Network Connection Fee.......................................................................................

Table 6. Example EVSE Unit Costs...................................................................................................... 10

Table 7. Example EVSE Installation Fees........................................................................................ 10

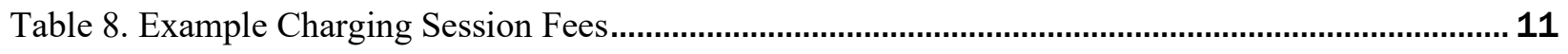




\section{Introduction}

This document is intended to serve as a program guide that federal agencies can use to develop their own policy document for workplace charging and assist agencies with successful implementation at their respective facilities. Developed by the Department of Energy (DOE) Federal Energy Management Program (FEMP) and National Renewable Energy Laboratory (NREL), this program guide offers suggested language that agencies may incorporate into their own policies to explain requirements for charging privately owned vehicles (POVs) on government-owned or leased property. This guide offers details for agency facility managers, transportation personnel, employees, and vendors regarding the charging of plug-in electric vehicles (PEVs) owned by employees and personnel at government-owned and leased buildings.

\subsection{Background}

The Fixing America's Surface Transportation Act (FAST Act) authorizes the U.S. General Services Administration (GSA) and other federal agencies to install, operate, and maintain electric vehicle supply equipment (EVSE) for POVs in parking areas under the custody, control, or administrative jurisdiction of GSA or the federal agency, and requires the collection of fees to recover the costs of installing, operating, and maintaining this EVSE. 42 U.S.C. $\$ 6364$ is provided in its entirety in Appendix A.

The requirements associated with federal agencies providing charging at publicly accessible sites are detailed in this document. It also describes when and how fees may be imposed to recover costs of electricity, as well as costs associated with EVSE units and their installations in various scenarios.

\subsection{Applicability}

This guide offers insights applicable to all agency-owned and GSA-leased buildings or facilities offering the use of EVSE or a 120-volt receptacle for the purpose of recharging a POV. All employees that work in applicable facilities may be authorized by agency policies to use EVSE to charge their POVs. Although such policies may apply to any building or facility operated and maintained by a commercial lessor offering the use of EVSE as part of a lease, they typically do not. Under the FAST Act, Federal agencies may designate responsibility for operating a workplace charging program to a third-party vendor at any type of facility.

\section{Model Program Guide}

This model program guide addresses seven topics relating to the planning and execution of a workplace charging program:

1. Roles and Responsibilities

2. Employee Survey

3. EVSE Planning, Acquisition, and Installation

4. Installation Costs/Fee Structure

5. Fee Collection

6. Program Management

7. Reporting.

Figure 1 illustrates the overall program steps outlined in this Guide. In addition, Appendix B contains a survey template that regional coordinators may provide to employees to assess interest in EVSE, and Appendix C 
outlines the calculations necessary to determine the fees that will appropriately recoup installation, operation, and maintenance costs to ensure the program is operated at a no-cost basis to the federal government.

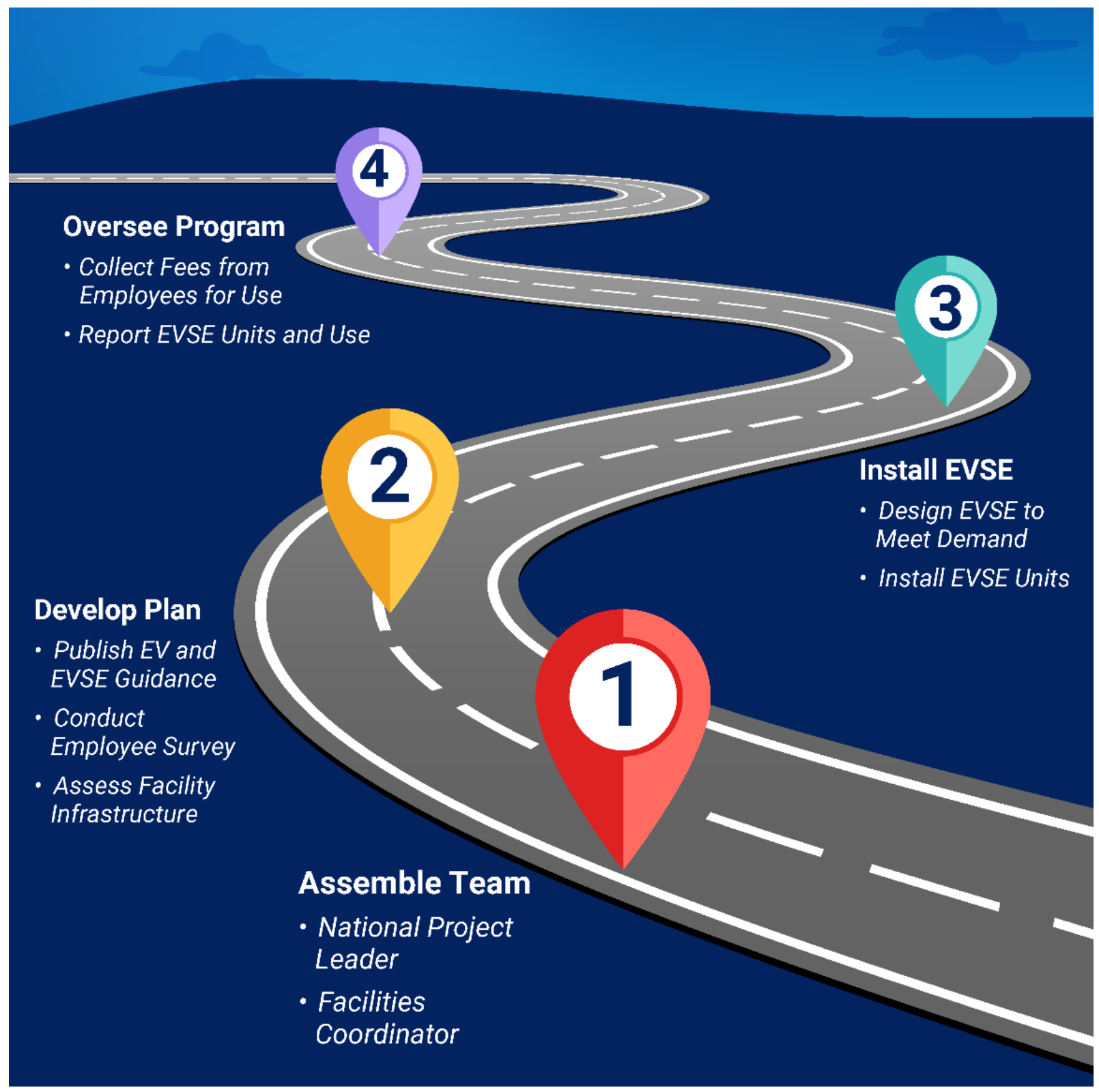

Figure 1. Workplace charging program roadmap

Illustration by Anthony Castellano, NREL

\subsection{Roles and Responsibilities}

Successful implementation of a workplace charging program requires that multiple departments engage in a coordinated effort. It is recommended that the key responsibilities in this effort be managed between the national level leader and a designated coordinator at each facility. In large organizations, a regional coordinator may be required to assist in managing a larger number of studies, projects, and reporting. Figure 2 outlines the interplay between the different responsibilities and actors in the absence of a regional coordinator. 


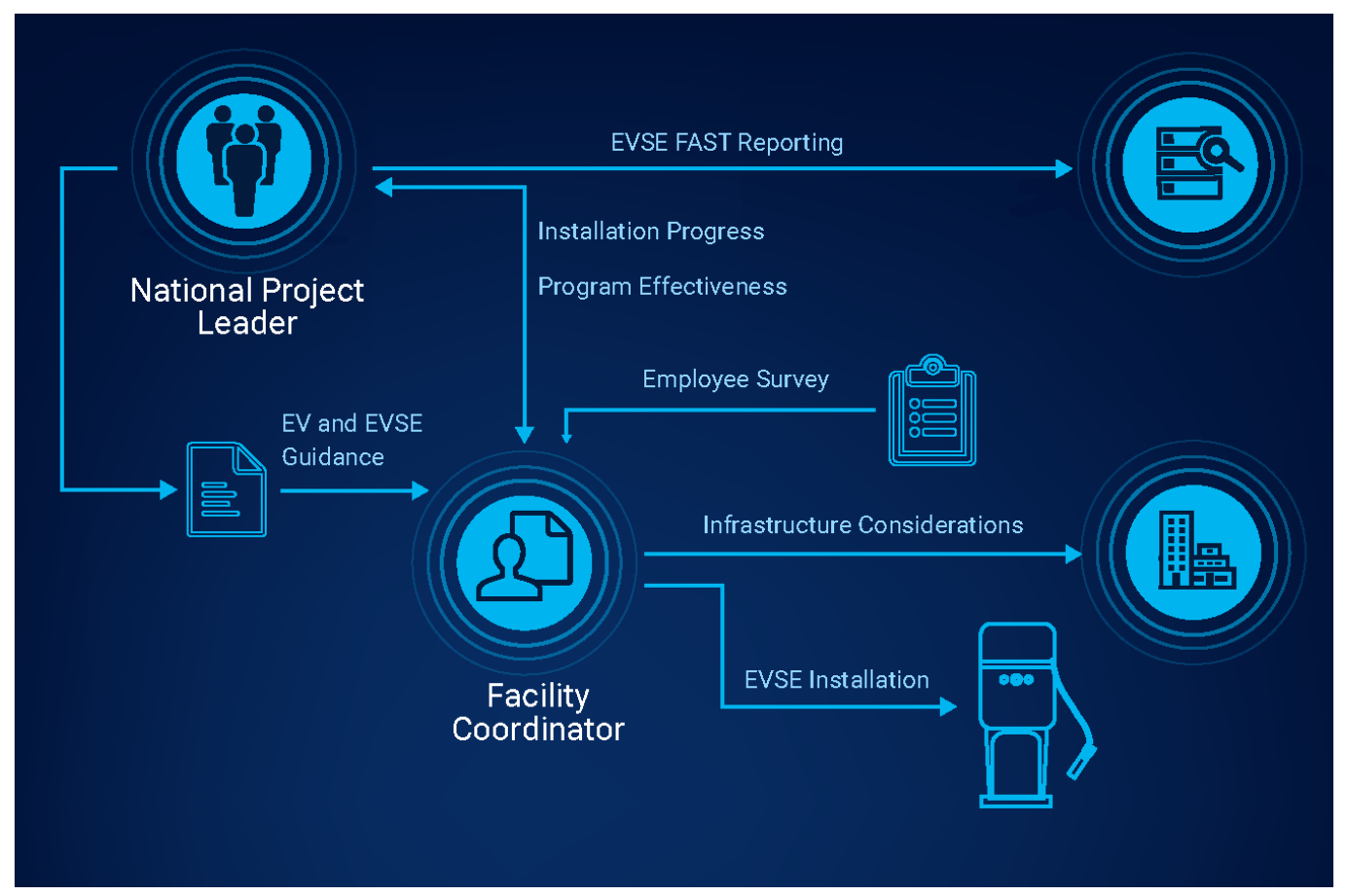

Figure 2. Workplace charging program workflow

Illustration by Anthony Castellano, NREL

\subsubsection{National Project Leader}

The national project leader is responsible for developing and updating workplace charging guidance, monitoring installation progress, troubleshooting concerns in consultation with regional or local coordinators, and providing EVSE installation data for reporting in the Federal Automotive Statistical Tool (FAST). The national project leader will convey the reference documents in Section 1 of this guidance and their contact information to the facility coordinators.

\subsubsection{Regional Coordinator (Optional)}

Agency structure and size will determine whether a regional coordinator is necessary to serve as an intermediary between the national project leader and each facility coordinator. A regional coordinator will report on the workplace charging program's effectiveness by reporting the data necessary for the FAST Act, in compliance with all federal and agency requirements.

\subsubsection{Facility Coordinator}

Facility coordinators will determine the number of necessary EVSE and locations for his or her installation. The individual will monitor the construction process and determine payment amounts and fee collection. The facility coordinator will report on the workplace charging program's effectiveness by reporting the data necessary for the FAST Act, in compliance with all federal and agency requirements.

The director or leader at each proposed facility will designate a workplace charging facility coordinator to serve as the program manager. General facility managers and sustainability coordinators are commonly assigned this duty, although other staff may be equally capable, if interested.

The primary objective of the national project leader and facility coordinator is to launch a successful program that serves the needs of users and complies with the FAST Act (excerpted in Appendix A) and specific agency requirements. 


\subsection{Employee Survey}

The facility coordinator should begin the planning process for their facility by assessing the need for EVSE for personal use through an employee survey. The survey's results will inform the number of EVSE required to serve the expected energy demand from the facility employees' PEVs. The sample employee survey in Appendix B highlights the daily commute distance of each employee, and the equations in Appendix C outline how this commute distance can be used to determine the length of time a vehicle must charge for Level 1 and Level 2 EVSE units. Section 2.3.1 explains the quantity of EVSE units that may be necessary to serve employees' energy needs based on their commute distances.

\subsection{EVSE Planning, Acquisition, and Installation}

To meet the energy needs as determined from survey responses, a facility coordinator should plan for and schedule the installation of EVSE. The following topics outline common EVSE solutions relevant to planning and scheduling the installation of workplace charging EVSE and are a key element in the FEMP Electric Vehicle Site Assessment Training offered through the Whole Building Design Guide. More information on choosing and installing EVSE may be found in NREL's Electric Vehicle Supply Equipment Tiger Team Site Assessment Findings from Army Facilities (Bennett et al. 2019).

\subsubsection{Number of EVSE Units and PEV-Dedicated Parking Spaces}

A facility coordinator should install an appropriate number of EVSE units to serve the demand identified in the results from the employee survey. Question 1 in the Employee Survey

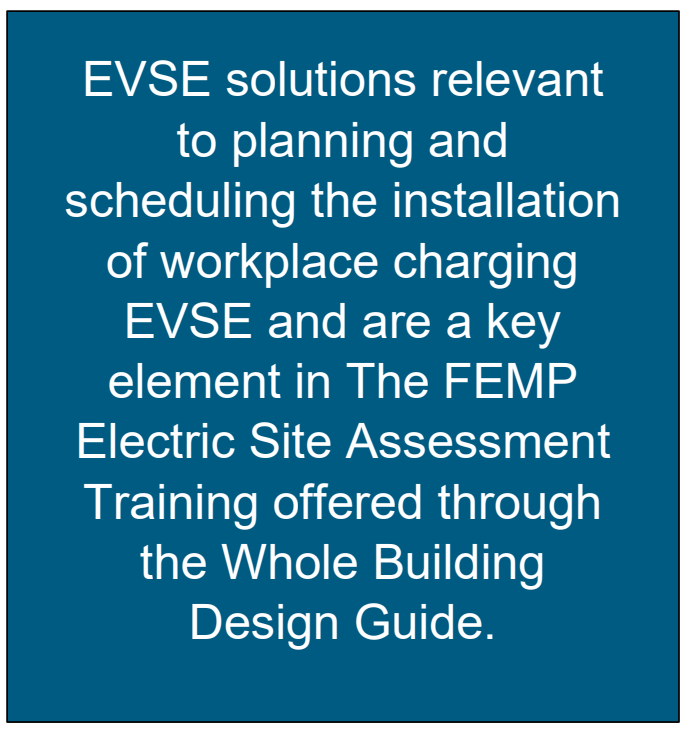
identifies the daily commute distance of each employee.

Facility coordinators can calculate the length of time that vehicles must charge for Level 1 and Level 2 EVSE units based on commute distance using Equations 1 and 2 in Appendix C. A Level 2 EVSE unit provides approximately 25 miles of range per hour, while Level 1 units provide up to 5 miles of range per hour. These miles charged/hour assumptions are estimates based on national vehicle data from 2019 sales highlighted in Table 1, and the associated calculations are provided in Appendix C Equations 1 and 2.

Level 1 EVSE can provide 40 miles of charging in an 8-hour workday. The shorter recharge times associated with the more powerful Level 2 units allow for two charging sessions per day up to 100 miles of range for each commuter. Therefore, under most circumstances, facility coordinators may assume that each Level 1 unit can serve one employee and each Level 2 unit can serve two employees each day. In the event one EVSE must serve multiple charge sessions each day, charge management software may be used to optimize their use. 
Table 1. Vehicle Charging Rates Based on Data From 2019 Sales

\begin{tabular}{lccc}
\hline EVSE & Power Rating & $\begin{array}{c}\text { Approximate } \\
\text { Charging Rate }\end{array}$ & Sessions per Day \\
\hline Level 1 & $1.8 \mathrm{~kW}$ & $5 \mathrm{mi} / \mathrm{hr}$ & 1 \\
Level 2 & $6.7 \mathrm{~kW}$ & $25 \mathrm{mi} / \mathrm{hr}$ & 2
\end{tabular}

\subsubsection{Example}

Consider a facility with $12 \mathrm{PEV}$-driving employees that have an average 12-mile commute (the national average commute length, according to the Federal Highway Administration National Household Travel Survey (Federal Highway Administration 2017). A standard Level 2 unit will provide 12 miles of range in a little over 30 minutes, while a $120-\mathrm{V}$ outlet for Level 1 charging will take almost 2 hours to provide the same amount of energy. This analysis is summarized in Table 2, and the associated calculations are listed in Appendix C under Equation 1.

Table 2. Vehicle Energy Needs and Charge Session Duration

\begin{tabular}{lccccc}
\hline EVSE & $\begin{array}{c}\text { Daily } \\
\text { Miles }\end{array}$ & $\begin{array}{c}\text { Vehicle } \\
\text { Efficiency }\end{array}$ & $\begin{array}{c}\text { Energy } \\
\text { Required }\end{array}$ & $\begin{array}{c}\text { Power } \\
\text { Rating }\end{array}$ & $\begin{array}{c}\text { Charging } \\
\text { Time }\end{array}$ \\
\hline Level 1 & $12 \mathrm{mi}$ & $3.6 \mathrm{mi} / \mathrm{kWh}$ & $3.3 \mathrm{kWh}$ & $1.8 \mathrm{~kW}$ & $1.8 \mathrm{hr}$ \\
Level 2 & $12 \mathrm{mi}$ & $3.6 \mathrm{mi} / \mathrm{kWh}$ & $3.3 \mathrm{kWh}$ & $6.7 \mathrm{~kW}$ & $0.5 \mathrm{hr}$
\end{tabular}

The simplest solution would be to assign 12 parking spaces for PEV charging and provide a $120-\mathrm{V}$ receptacle for each. This will require the smallest infrastructure investment, because all PEVs are sold standard with a portable Level 1 EVSE. Each employee will be able to plug their vehicle into a nearby receptacle and may receive as much as 40 miles of range within a standard 8-hour workday.

Alternatively, if the facility can only spare six parking spaces for PEV charging or is pursuing a networked solution only available with Level 2 EVSE, then Level 2 units may be preferable. The faster charging rate of Level 2 units will enable the 12 employees to use the six units if they each occupy the parking space for half of the workday or every other day. This faster recharge time will enable them to move their vehicle in the middle of the day so that a second vehicle may use the charger in the afternoon. The higher charging rate of the Level 2 unit will provide as much as 100 miles of range in approximately 4 hours.

\subsubsection{Location}

There are several key construction activities that can cause EVSE installation costs to rise rapidly. For example, trenching required to run wiring from the electric service panel to the EVSE can be as high as $\$ 150 / \mathrm{ft}$; therefore, to reduce the amount of trenching needed, it is strongly recommended that facility coordinators plan PEV parking as close as possible to the nearest electric service panel. This will limit the overall trenching cost, which can be as high as $\$ 150 / \mathrm{ft}$.

\subsubsection{Unit Selection}

For most applications of workplace charging, Level 2 units will prove to be the most practical application. They provide a much faster charge rate than Level 1 units and are considerably less expensive to purchase and install than DC fast chargers (DCFC). Dual-port units-EVSE with two charging cords - are generally more economical due to their limited infrastructure costs. Level 2 units also provide the option for network connections, which is a feature that may increase unit costs, but also provides simpler options for reporting and transaction processing. It is important to address cybersecurity concerns associated with EVSE through the procurement process and by taking other precautions, as explained in Vehicle Cybersecurity Threats and Mitigation Approaches (Hodge, et. al. 2019). 


\section{Level 2 units...provide a}

much faster charge rate

than Level 1 units and

are considerably less

expensive to purchase

and install than DCFC.
From the Level 2 example in Section 2.3.1.1 it is more economical to install three Level 2 dual-port pedestal units to serve the vehicles parked in the six allotted spots, rather than six Level 2 single-port pedestal units. However, there are also instances where basic wall-mount units are the most economical option, because they typically cost less per unit, and often do not require any trenching.

GSA Fleet offers a pre-negotiated, multi-award blanket purchase agreement (BPA) for Level 1, Level 2, and DCFC stations. The BPA includes products from different

manufacturers and data network plans, but it does not include installation services. More information on acquiring EVSE through GSA's BPA is available at http://gsa.gov/evse.

\subsubsection{Electrical Capacity}

The facility coordinator should consult with an electrician or engineer to determine electrical capacity readily available at the facility. In assessing the available electrical capacity at the facility, the coordinator will confront decisions regarding whether upgrades to electric panels and transformers, among other equipment, may be necessary. They may find, for example, that there is insufficient space or electrical capacity in nearby service panels to support the EVSE units desired. If so, a new service panel may need to be installed either in the electrical room or near a transformer. The transformer may need to be upgraded as well.

Level 2 EVSE ports are typically rated at 30 or 32 Amps (A) and operate on single-phase 208- or 240-Volt (V) power. Level 1 EVSE units are typically rated at 12 or $16 \mathrm{~A}$ and operate on $120-\mathrm{V}$ power. EVSE is considered a continuous load for the purposes of the National Electrical Code and therefore requires $125 \%$ overcurrent protection. A standard 32-A Level 2 port will require a 40-A circuit breaker. These basic AC installation requirements, highlighted in Table 3 , are also covered in the FEMP Electric Vehicle Site Assessment Training and may be used as a

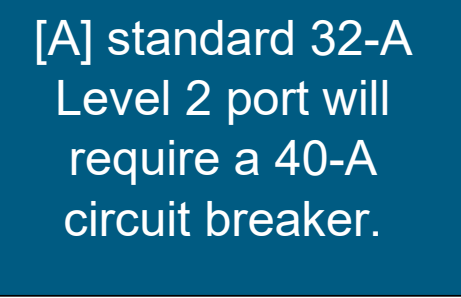
way to estimate electrical capacity before consulting a professional

Certain dual-port EVSE units can share the electrical capacity from a single circuit breaker. If two vehicles are charging at the same time — one on each port - a power share hardware kit can split one 40-A circuit to minimize infrastructure costs with minimal impact on vehicle charging. This allows a dual-port EVSE unit to supply the full EVSE power to one vehicle or to split the power between two. The FEMP Electric Vehicle Site Assessment Training covers these simple forms of charge management, as well as more sophisticated smart charge management solutions and how they can support workplace charging programs.

Table 3. EVSE Installation Requirements

\begin{tabular}{lcccc}
\hline EVSE & Electrical Service & Breaker Positions & Connection Type & $\begin{array}{c}\text { Connection } \\
\text { Options }\end{array}$ \\
\hline Level 1 & $120 / 240 \mathrm{~V}, 1 \Phi$ & $1(20 \mathrm{~A})$ & Line-Neutral & L1-N or L2-N \\
Level 1 & $208 Y / 120 \mathrm{~V}, 3 \Phi$ & $1(20 \mathrm{~A})$ & Line-Neutral & A-N, B-N, or C-N \\
Level 2 & $120 / 240 \mathrm{~V}, 1 \Phi$ & $2(40 \mathrm{~A})$ & Line-Line & L1-L2 \\
Level 2 & $208 Y / 120 \mathrm{~V}, 3 \Phi$ & $2(40 \mathrm{~A})$ & Line-Line & A-B, B-C, or C-A
\end{tabular}

DCFC operate on three phase $480-\mathrm{V}$ power inputs and higher amperage than Level 2 units. In addition to the electrical upgrades typically necessary to support DCFC, the intermittent high-power loads for fast chargers 
typically incur costly electricity bills due to peak demand charges. In federal workplaces, DCFC are typically only deployed at locations where high traffic and short dwell times require a quick charging experience.

\subsubsection{Grant Programs}

Throughout the country, utilities, states, and private enterprises offer grants for the installation of EVSE. For example, in several states, the Environmental Mitigation Trust from the Volkswagen ${ }^{\circledR}$ diesel emissions settlement can cover up to $100 \%$ of EVSE unit and installation costs. Project leaders and coordinators should check the Alternative Fuel Data Center Laws and Incentives Database for more information and reach out to the nearest Clean Cities Coalition Coordinator for local support and questions about federal eligibility for specific grant programs.

\subsubsection{Alternative to New Unit Installation}

Parking lots may have existing $120-\mathrm{V}$ electrical receptacles that can be used in combination with portable Level 1 EVSE units to connect to employee vehicles. In these cases, the most cost-effective option for the employees is to use the Level 1 EVSE units that come standard with most EVs.

If an agency fleet has installed charging equipment primarily for the fleet and can accommodate incidental POV access to and charging at these EVSE at certain hours or on certain chargers, then facilities may pursue this alternative as well. (Office of Federal Sustainability Council on Environmental Quality, 2016a).

In both of these cases, employees will need to reimburse the facility for the cost of electricity but not the cost of the unit or installation. 42 U.S.C. $\S 6364$.

\subsection{Installation Costs/Fee Structure}

To provide this charging service at a no-cost basis to the government, per the FAST Act, it is necessary to collect fees from POV charging at government-owned EVSE, which may include electricity costs, unit and installation costs, network fees, and transaction fees. While some agencies might employ the support of thirdparty network providers to oversee or manage these transactions and collect fees, the units will still be installed and owned by the agency. In these instances, these fees will have to cover not only the electricity, unit, and installation expenses, but also network bills and transaction fees. DOE developed a Federal Workplace Charging Fee Calculator that helps agencies input their actual costs and determine appropriate fees.

\subsubsection{Electricity Costs}

Under all POV charging scenarios, installed EVSE will supply POVs with electricity that the agency purchases. Pursuant to the FAST Act, recouping this cost of electricity is a requirement for all workplace charging programs as a component of the fee structure. The cost of electricity for each charging event may be estimated or metered.

\subsubsection{Estimated}

The simplest and most affordable EVSE units are the ones without metering capabilities or a network connection. When installing these simple chargers, it is necessary to estimate the energy that will be provided during each charge session and the price of that energy. According to the U.S. Energy Information Administration, the average price of electricity in January 2019 was $\$ 0.103 / \mathrm{kWh}$ for commercial customers. According to Equation 3 in Appendix C, each vehicle should be charged \$0.34 per charge session for the electricity portion of their fee (Table 4).

Table 4. Estimated Electricity Cost per Charging Session

\begin{tabular}{ccc}
\hline Energy Required & Electricity Rate & Electricity Fee \\
\hline $3.3 \mathrm{kWh}$ & $\$ 0.103 / \mathrm{kWh}$ & $\$ 0.34$
\end{tabular}




\subsubsection{Metered}

Alternatively, some EVSE directly measure the amount of energy used per session via an internal electricity meter. In this scenario, rather than the facility coordinator estimating the energy consumed, the EVSE would provide exact figures for each charging session.

In many cases, agencies employ a third-party EVSE provider to oversee and manage the transaction processing for each charge session. In addition to the network connection fees, outlined below, the provider likely will impose a transaction fee on the agency, as an additional cost that must also be included in the money recouped, pursuant to the FAST Act.

\subsubsection{Demand Charges}

Demand charges, which are typically based on the highest 15-minute power demand in a month, can significantly increase the cost of charging PEVs. Facility coordinators should consider strategies to avoid high demand charges, such as EVSE units that can curtail charging at periods when the facility is operating at peak demand.

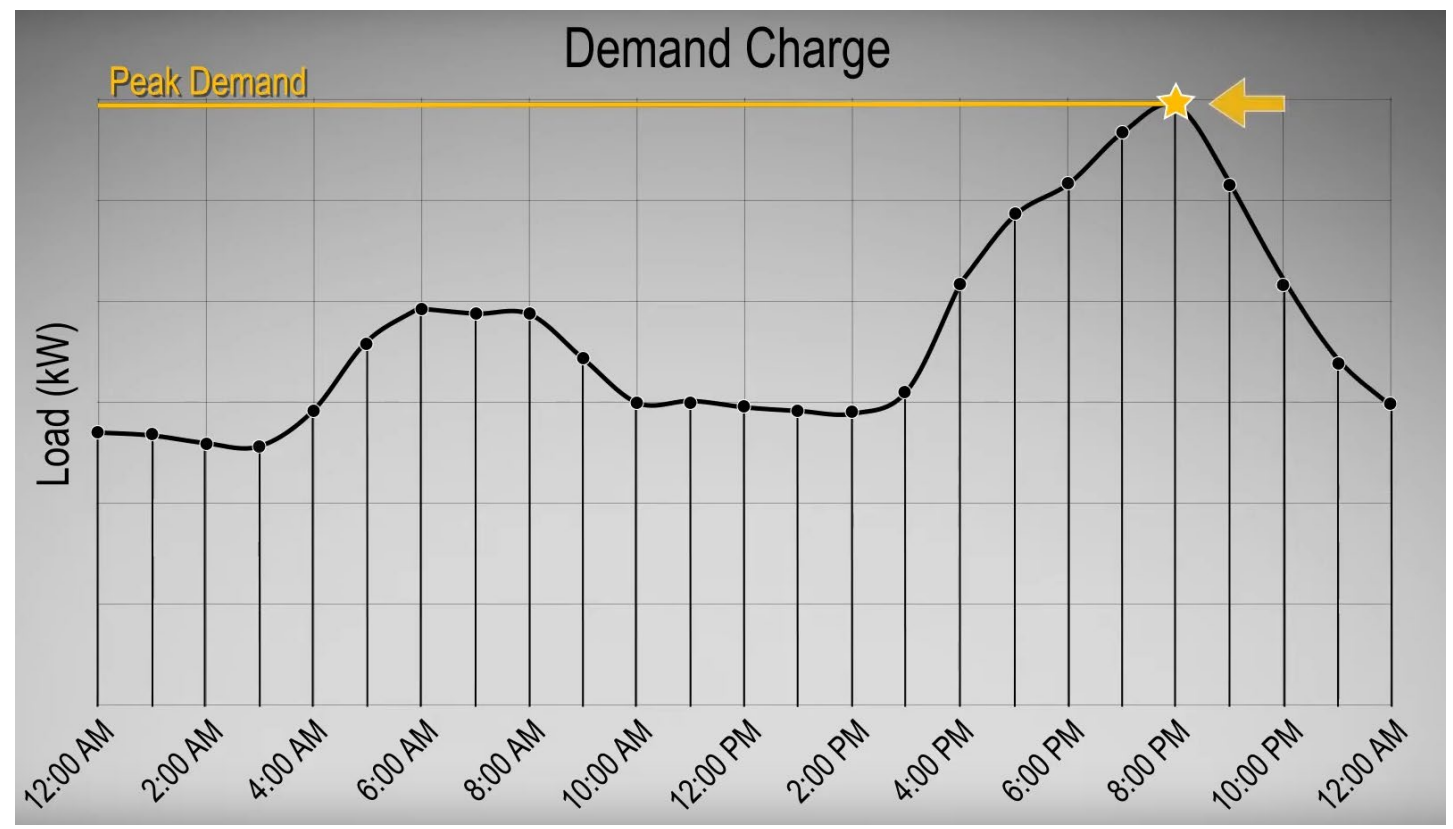

Figure 3. Peak demand illustration

Source: "Federal Fleet Training: Electric Vehicle Financial Consideration"

\subsubsection{Network Connection}

Smart chargers rely on network connections to provide data on vehicle energy consumption via cellular network, collect payment from users, restrict access, set fees, and/or complete other tasks. However, this cellular connection is typically non-abrasive to the facility's IT infrastructure and does not require direct connection to any government system. These smart chargers may increase the cost of the unit and require internet connectivity that entails an additional network fee (usually \$270-\$300 per year per port), which also must be recouped. If the EVSE incurs such monthly or annual network fees, a portion of the fee for POV use must also account for these expenses. An example network contract on the GSA Blanket Purchase Agreement costs

[S]mart chargers may increase the cost of the unit and require internet connectivity that entails an additional network fee. 
approximately $\$ 280$ per port each year. As detailed below, this annual network fee may be distributed across each charging session by assuming a standard 261 workdays in a year.

Under most workplace charging programs, it is reasonable to assume that each Level 2 EVSE port will be used twice during each workday. Network connections are less common with Level 1 EVSE connections. Using Equation 4 in Appendix C, the standard Level 2 system would require approximately $\$ 0.54 /$ session network fee.

This fee does not apply to basic EVSE units without network connections or to $120-\mathrm{V}$ receptacles where employees bring their own charger and are charged based on estimated energy use. As an example, this fee is highlighted in Table 5.

Table 5. Example Network Connection Fee

\begin{tabular}{lccc}
\hline EVSE & $\begin{array}{c}\text { Annual } \\
\text { Network Fee } \\
\text { per Port }\end{array}$ & $\begin{array}{c}\text { Sessions per } \\
\text { Year }\end{array}$ & $\begin{array}{c}\text { Network Fee } \\
\text { per Port }\end{array}$ \\
\hline 120-V Receptacle & - & 261 & - \\
Networked Level 2 & $\$ 280.00$ & 522 & $\$ 0.54$
\end{tabular}

\subsubsection{Unit and Installation}

Much like the network fees, the EVSE unit and installation costs must be distributed based on an assumed number of sessions per month; however, unlike the annual structure of the network contracts, the cost of the unit and installation may be amortized over the life of the system. This amortization period is estimated to be 10 years for the EVSE unit, while the electric infrastructure should last longer and may be amortized over a 40-year period. (Office of Federal Sustainability Council on Environmental Quality, 2016b).

Although all POV access to agency-owned EVSE must be provided at a no-cost basis to the federal government, section 4 of 42 USC $\S 6364$ details a few exceptions regarding unit and installation costs. Agencies are not required to include the unit and installation costs in the EVSE fee structure if the units were installed prior to December 4, 2015 or are primarily for use by the federal fleet with only incidental POV use.

\subsubsection{Unit Costs}

EVSE unit costs vary based on their charging level and control features. Approximate costs are based on prices available from the GSA BPA and GSA Advantage. The following unit costs are calculated from Equation 5 in Appendix $\mathrm{C}$ and summarized in Table 6.

- Level 1 receptacles should be commercial-grade and weather-resistant, with ground-fault circuit interrupters. Although they do not provide a direct connection to EVs, they are ideal for providing a connection to the standard portable Level 1 EVSE provided with most PEVs. Level 1 receptacles typically cost around $\$ 100$, which correspond to a unit fee of $\$ 0.04 /$ session amortized over 10 years.

- Fixed wall-mount single-port Level 1 units provide an easier connection for users and may be preferred. The additional infrastructure eliminates the need for users to bring their own device but are more costly than a basic receptacle. These units typically cost around $\$ 400$, which corresponds to a unit fee of $\$ 0.15 /$ session.

- Simple (non-networked) wall-mount single-port Level 2 EVSE units provide approximately four times as much power as a Level 1 unit and can charge multiple PEVs in a day. These units typically cost around $\$ 600$, which corresponds to a unit fee of $\$ 0.11 /$ session. 
- Simple (non-networked) pedestal dual-port Level 2 EVSE units can be installed in the middle of a parking lot, unlike wall-mount units. These dual port units also provide two separate EVSE ports and can serve up to 4 vehicles per day. They cost approximately $\$ 2,000$ per unit and when distributed across two ports and amortized over 10 years, the cost corresponds to a unit fee of $\$ 0.19 /$ session, given the assumed cost of $\$ 2,000$.

- Networked pedestal or wall-mount dual-port Level 2 EVSE units can collect payment from employees and provide data on utilization. They are more expensive than basic dual-port units but also can serve up to four vehicles per day. Their approximate unit cost is $\$ 7,000$, which corresponds to a $\$ 0.67 /$ session unit fee.

Table 6. Example EVSE Unit Costs

\begin{tabular}{lcccc}
\hline EVSE & $\begin{array}{c}\text { Total Unit } \\
\text { Cost }\end{array}$ & $\begin{array}{c}\text { Amortization } \\
\text { Period }\end{array}$ & $\begin{array}{c}\text { Sessions per } \\
\text { Year }\end{array}$ & Unit Fee \\
\hline 120-V Receptacle & $\$ 100$ & $10 \mathrm{yrs}$ & 261 & $\$ 0.04$ \\
\hline Level 1 Wall-mount & $\$ 400$ & $10 \mathrm{yrs}$ & 261 & $\$ 0.15$ \\
\hline Level 2 Wall-mount & $\$ 600$ & $10 \mathrm{yrs}$ & 522 & $\$ 0.11$ \\
$\begin{array}{l}\text { Level 2 Pedestal } \\
\text { (Dual Port) }\end{array}$ & $\$ 2,000$ & $10 \mathrm{yrs}$ & 1,044 & $\$ 0.19$ \\
$\begin{array}{l}\text { Networked Level 2 } \\
\text { (Dual Port) }\end{array}$ & $\$ 7,000$ & $10 \mathrm{yrs}$ & 1,044 & $\$ 0.67$ \\
\hline
\end{tabular}

\subsubsection{Installation Costs}

Installation costs are highly variable based on the facility and the placement of the charger. Nearly all installations will require new circuit breakers, conduit, and wiring at a minimum; however, the variation in trenching needs from site to site result in a wide range of potential installation costs on a per-port basis. Some locations can be retrofitted with a conduit pathway during a remodel or construction of a new parking garage or facility. GSA's PBS Building Standards (P100) Section 6.5.7.8 requires that for new construction, conduit pathway infrastructure shall be provided for both POV and government-owned EVSE and located as close as possible to the building's electrical supply service while also ensuring the EVSEs are conveniently located for drivers. The calculations in Table 7 are an approximation, illustrating potential fees; however, facility coordinators should determine actual installation costs and then determine the installation fee per charging session, using Equation 6 in Appendix C.

Table 7. Example EVSE Installation Fees

\begin{tabular}{lcccc}
\hline EVSE & $\begin{array}{c}\text { Installation } \\
\text { Cost per Port }\end{array}$ & $\begin{array}{c}\text { Amortization } \\
\text { Period }\end{array}$ & $\begin{array}{c}\text { Sessions per } \\
\text { Year }\end{array}$ & $\begin{array}{c}\text { Installation } \\
\text { Fee per Port }\end{array}$ \\
\hline 120-V Receptacle & $\$ 500$ & $40 \mathrm{yrs}$ & 261 & $\$ 0.05$ \\
Networked Level 2 & $\$ 2,000$ & $40 \mathrm{yrs}$ & 522 & $\$ 0.10$
\end{tabular}

\subsubsection{Total Fee}

Depending on each facility's specific scenario, the total session fee that should be charged to an employee will vary; however, based on the various expenses, the fee should be calculated as the sum of each of the expenses highlighted above. The equation below summarizes this approach and Table 8 provides a summary of each scenario.

$$
\text { Total Fee }=\text { Electricity Fee }+ \text { Network Fee }+ \text { Unit Fee }+ \text { Installation Fee }
$$


Table 8. Example Charging Session Fees

\begin{tabular}{lccccc}
\hline EVSE & $\begin{array}{c}\text { Electricity } \\
\text { Fee }\end{array}$ & Network Fee & Unit Fee & $\begin{array}{c}\text { Installation } \\
\text { Fee }\end{array}$ & $\begin{array}{c}\text { Total Session } \\
\text { Fee }\end{array}$ \\
\hline 120-V Receptacle & $\$ 0.34$ & - & $\$ 0.04$ & $\$ 0.05$ & $\$ 0.43$ \\
Networked Level 2 & $\$ 0.34$ & $\$ 0.54$ & $\$ 0.67$ & $\$ 0.10$ & $\$ 1.65$
\end{tabular}

\subsection{Fee Collection}

Fees collected by an agency for workplace charging of employee POVs must be deposited monthly in the agency's respective appropriations account with the Treasury and those fees must be reimbursed to the agency's appropriations account for the operation of the building. 42 U.S.C. § 6364(2)(B). Facilities may work with their accounting departments, the U.S. Department of Treasury, and charging service providers to collect session fees. Many charging service providers collect fees from users through web applications. Funds from each element of the fee structure, such as electricity and installation costs, may be allotted separately to different departments.

The U.S. Department of Treasury can arrange this reimbursement process using a pay.gov account, which accepts ACH debits, credit card, debit cards, or digital wallet payments. The most common of these fee collection methods are detailed below.

\subsubsection{Pay.gov}

Agencies can customize a payment system through this Treasury-managed e-billing service that will send a monthly bill to employees, allow them to pay the bill online, and deposit the money in the Treasury, from which it can be applied directly to the facilities hosting workplace charging stations. Agencies may work with Pay.gov's implementation team at pay.gov@fiscal.treasury.gov to establish a web-based collection system using either a general form or unique bill issued for each employee. If pursuing this method of fee collection, the employee submits payment with debit, credit, or digital wallet using either Pay.gov's Forms Service for one-time payments or eBilling service for recurring biweekly/monthly/annual billing payments. Collected funds are deposited directly into the Agency Location Code appropriations account for the operations of the building where the charging station is located.

\subsubsection{Payroll Deduction}

Agencies may alternatively withdraw the fee from employee's payroll as a post-tax deduction and then deposit the money into a Treasury account. The facility coordinator or national project leader should work with human resources to implement this approach.

\subsubsection{Third-Party Vendor}

A third-party vendor, such as a charging station network, parking kiosk, or a parking operator, could manually or electronically collect fees and send the agency checks, direct debit deposits, or wire transfers on a periodic basis. They can work in conjunction with pay.gov as well. The vendor will usually charge a fee for their services. This method can be the easiest to navigate, as many station vendors/manufacturers/network providers will work with agencies to manage your payments within their systems and have vast experience doing so. 


\subsection{Program Management}

A facility coordinator should monitor the EVSE stations and address issues as they arise.

\subsubsection{Maintenance}

Most stations come with a one-year parts and service warranty, and some networked EVSE include maintenance as part of the networking contract. For others, it is typically possible to purchase special packages for prolonged maintenance and warranties. Maintenance for EVSE can include programming updates, as well as physical damage to the equipment. Programming issues typically require consultation with the EVSE vendor or station provider. Physical damage may require support from an electrician and other maintenance staff, or it may require removing and replacing the EVSE unit. In addition, when stations are ready for replacement, many vendors offer deals to replace existing` nonfunctioning EVSE with new stations for a 30\%-70\% discount on new stations.

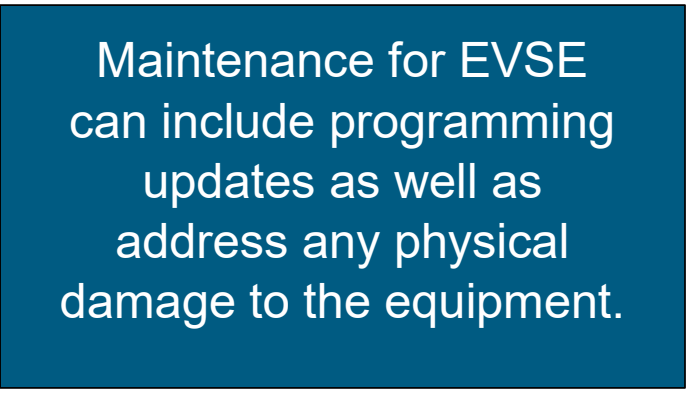

\subsubsection{Access}

Each EVSE unit should have a clear access policy that may include fleet vehicles, employee POVs, and public access. In some cases, fleet EVSE may only be available to POVs at certain hours (e.g., 9 a.m.-4 p.m.) and reserved for government-owned vehicles the rest of the time. In addition, signage helps users and nonusers identify where drivers should park and where non-EV drivers may not park. The signage and access limitations can serve as a way to restrict or limit certain behavior and can be used as a promotional opportunity for the workplace charging program.

\subsubsection{Oversubscription}

Oversubscription occurs when there are insufficient EVSE to serve the number of PEVs that seek charging. The facility coordinator can address oversubscription by creating a waitlist, limiting EVSE access to three days per week for each vehicle, requiring PEV owners to stop charging at noon to allow others to use the units, or implementing another system. The facility coordinator may create an email listserv or another communication system to institute a waitlist and notify when charging is complete at specific EVSE units. The facility coordinator should notify the national project leader if existing EVSE units are oversubscribed.

\subsection{Reporting}

The GSA Administrator is required to submit to Congress information regarding the number of EVSE units at Federal agencies. 42 U.S.C. §6364(5). Facilities must report data on EVSE installations for workplace or fleet charging to the national project leader for the purpose of submitting this information into FAST. The data submitted to FAST will include the location of the EVSE unit, number and type of EVSE connectors, installation costs, and whether access is available to POVs, fleet vehicles, and/or the public at large. A Microsoft Excel template for data submission is available at https://fastweb.inl.gov/help/.

Agencies or building management may require additional reporting. For example, in GSA buildings, GSA Order: PBS 5605.1 requires, "[that for EVSEs Installed for Use by GSA Employees], Facility Managers shall report to the respective GSA Regional Facilities Management Office the (1) number and type of EVSEs installed, (2) cost of the hardware and installation, and (3) fee assessed to authorized users." 
Agencies also track building energy intensity figures. Although electricity use is offsetting gasoline, building management may express concern about rising energy costs. The project manager can track these costs as described above but it is also helpful to keep in mind that the average workplace charging station uses less than $10 \mathrm{kWh}$ of electricity each day. This is less than the energy consumed by four desktop computers and monitors running for a 24-hour period. As noted in Section 2.4, DOE hosts a Federal Workplace Charging Fee Calculator that provides agencies with a tool to input their actual costs and determine appropriate fees.

As agency workplace charging programs grow, the national project leader can monitor the progress of these programs through the collection of utilization data to plan for the continued growth of these programs. This utilization data can be collected through networked EVSE with online dashboards. If this data is not available, the facility coordinator may provide the national project leader with a summary of EVSE demand and availability to determine when additional infrastructure development is necessary. 


\section{References}

DOE (2017). "Implementing Workplace Charging Within Federal Agencies."

https://afdc.energy.gov/files/u/publication/federal_wpc_case_study.pdf.

GSA (2016). “5605.1 PBS Electric Vehicle Supply Equipment Infrastructure Management.”

https://www.gsa.gov/directives-library/electric-vehicle-supply-equipment-infrastructure-management-56051pbs.

Hodge, Cabell, Hauck, Konrad, Gupta, Shivam, and Bennett, Jesse C. Vehicle Cybersecurity Threats and Mitigation Approaches. United States: N. p., 2019. Web. doi:10.2172/1559930.

Office of Federal Sustainability Council on Environmental Quality (2016a). "Guidance for Federal Agency Implementation of Workplace Charging Pursuant to the Fixing America's Surface Transportation Act: Level 1 Charging Receptacles.” https://www.sustainability.gov/pdfs/guidance_fed_workplace_charging.pdf.

Office of Federal Sustainability Council on Environmental Quality (2016b). "Guidance for Federal Agency Implementation of Workplace Charging Pursuant to the Fixing America's Surface Transportation Act: Electric Vehicle Supply Equipment."

https://obamawhitehouse.archives.gov/sites/default/files/guidance_for_federal_agency_implementation_of_wo rkplace_charging_electric_vehicle_supply_equipment.pdf.

"Public Law 114-94, Fixing America's Surface Transportation (FAST) Act, Sec. 1413 § 151: National electric vehicle charging and hydrogen, propane, and natural gas fueling corridors." December 4, 2016. 42 U.S. Code $\S$ 6364 (full text in Appendix A). https://www.congress.gov/114/plaws/pub194/PLAW-114pub194.htm.

U.S. Department of Transportation Federal Highway Administration (2017). "Summary of Travel Trends 2017 National Household Travel Survey." Accessed July 22, 2020.

https://nhts.ornl.gov/assets/2017_nhts_summary_travel_trends.pdf. 


\section{Appendix A: 42 U.S.C. §6364. Operation of battery recharging stations in parking areas used by Federal employees}

(1) Authorization

(A) In general

The Administrator of General Services may install, construct, operate, and maintain on a reimbursable basis a battery recharging station (or allow, on a reimbursable basis, the use of a 120-volt electrical receptacle for battery recharging) in a parking area that is in the custody, control, or administrative jurisdiction of the General Services Administration for the use of only privately owned vehicles of employees of the General Services Administration, tenant Federal agencies, and others who are authorized to park in such area to the extent such use by only privately owned vehicles does not interfere with or impede access to the equipment by Federal fleet vehicles.

(B) Areas under other Federal agencies

The Administrator of General Services (on the request of a Federal agency) or the head of a Federal agency may install, construct, operate, and maintain on a reimbursable basis a battery recharging station (or allow, on a reimbursable basis, the use of a 120-volt electrical receptacle for battery recharging) in a parking area that is in the custody, control, or administrative jurisdiction of the requesting Federal agency, to the extent such use by only privately owned vehicles does not interfere with or impede access to the equipment by Federal fleet vehicles.

(C) Use of vendors

The Administrator of General Services, with respect to subparagraph (A) or (B), or the head of a Federal agency, with respect to subparagraph (B), may carry out such subparagraph through a contract with a vendor, under such terms and conditions (including terms relating to the allocation between the Federal agency and the vendor of the costs of carrying out the contract) as the Administrator or the head of the Federal agency, as the case may be, and the vendor may agree to.

(2) Imposition of fees to cover costs

\section{(A) Fees}

The Administrator of General Services or the head of the Federal agency under paragraph (1)(B) shall charge fees to the individuals who use the battery recharging station in such amount as is necessary to ensure that the respective agency recovers all of the costs such agency incurs in installing, constructing, operating, and maintaining the station.

(B) Deposit and availability of fees

Any fees collected by the Administrator of General Services or the Federal agency, as the case may be, under this paragraph shall be-

(i) deposited monthly in the Treasury to the credit of the respective agency's appropriations account for the operations of the building where the battery recharging station is located; and 
(ii) available for obligation without further appropriation during-

(I) the fiscal year collected; and

(II) the fiscal year following the fiscal year collected.

(3) No effect on existing programs for House and Senate

Nothing in this subsection affects the installation, construction, operation, or maintenance of battery recharging stations by the Architect of the Capitol-

(A) under section 2171 of title 2, relating to employees of the House of Representatives and individuals authorized to park in any parking area under the jurisdiction of the House of Representatives on the Capitol Grounds; or

(B) under section 2170 of title 2, relating to employees of the Senate and individuals authorized to park in any parking area under the jurisdiction of the Senate on the Capitol Grounds.

(4) No effect on similar authorities

Nothing in this subsection-

(A) repeals or limits any existing authorities of a Federal agency to install, construct, operate, or maintain battery recharging stations; or

(B) requires a Federal agency to seek reimbursement for the costs of installing or constructing a battery recharging station-

(i) that has been installed or constructed prior to December 4, 2015;

(ii) that is installed or constructed for Federal fleet vehicles, but that receives incidental use to recharge privately owned vehicles; or

(iii) that is otherwise installed or constructed pursuant to appropriations for that purpose.

(5) Annual report to Congress

Not later than 2 years after December 4, 2015, and annually thereafter for 10 years, the Administrator of General Services shall submit to the Committee on Transportation and Infrastructure of the House of Representatives and the Committee on Environment and Public Works of the Senate a report describing-

(A) the number of battery recharging stations installed by the Administrator on the Administrator's own initiative under this subsection;

(B) requests from other Federal agencies to install battery recharging stations; and

(C) the status and disposition of requests from other Federal agencies.

(6) Federal agency defined

In this subsection, the term "Federal agency" has the meaning given the term "Executive agency" in section 105 of title 5 and includes-

(A) the United States Postal Service;

(B) the Executive Office of the President;

(C) the military departments (as defined in section 102 of title 5); and 
(D) the judicial branch.

(7) Effective date.

This subsection shall apply with respect to fiscal year 2016 and each succeeding fiscal year. ( Pub. L. 114-94, div. A, title I, §1413(c), Dec. 4, 2015, 129 Stat. 1418.) 


\section{Appendix B: Template for Employee Survey}

Plug-in electric vehicles (PEVs) use electricity as either their primary fuel or to improve fuel efficiency. Over 25 PEV models are available. We are considering developing an installation and region PEV policy to assist employees who drive PEVs to work. Your responses to this survey will be used to determine employee interest. Participation in this survey is voluntary.

1) If you drive to work, approximately how far is your trip (one way)?
a) Less than 10 miles
b) $10-25$ miles
c) $26-50$ miles
d) More than 50 miles

2) Throughout the workday, what is your usual travel pattern?
a) I stay at the worksite and do not move my vehicle.
b) I leave the worksite to move my vehicle at least once.

3) Do you own or are you considering purchasing or leasing an electric or plug-in hybrid electric vehicle?
a) Yes, I already own one.
b) Yes, I'm considering purchasing in next 6 months.
c) Yes, I'm considering purchasing in 12-24 months.
d) No

4) If yes, what type of vehicle are you most interested in?
a) Plug-in hybrid electric vehicle (i.e., Chevy Volt, Ford C-MAX energi, and so on)
b) Electric vehicle (i.e., Nissan Leaf, BMW i3, and so on)

5) Do you or would you have the ability to install a charging station at your residence?
a) Yes
b) No
c) I don't know.

6) If [Agency] installs electric vehicle charging stations at your facility, would you use them?
a) Yes
b) No

7) What is the most you would be willing to pay for use of the charging stations?
a) \$0-\$2 per charging session
b) $\$ 2-\$ 6$ per charging session
c) $\$ 0-\$ 20$ per month
d) \$21-\$40 per month 


\section{Appendix C: POV Fee Calculations}

\section{Equation 1: Energy per Charge Session}

K-Energy per session (kWh)

Dc-Commute distance (miles)

ev-Vehicle efficiency (miles/kWh)

$$
\begin{gathered}
K=\frac{D_{C}}{e_{V}} \\
K=\frac{12 \mathrm{mi}}{3.6 \mathrm{mi} / \mathrm{kWh}}=3.3 \mathrm{kWh}
\end{gathered}
$$

\section{Equation 2: Length of Charge Session}

$T_{E}$ - Time spent charging (hours)

$P_{E}-$ Power rating of EVSE $(k W)$

$\mathrm{K}$ - Energy per session ( $\mathrm{kWh}$ )

$$
\begin{gathered}
T_{E}=\frac{K}{P_{E}} \\
T_{E 1}=\frac{3.3 \mathrm{kWh}}{1.8 \mathrm{~kW}}=1.8 \mathrm{hr} / \mathrm{session} \quad T_{E 2} \frac{3.3 \mathrm{kWh}}{6.7 \mathrm{~kW}}=0.5 \mathrm{hr} / \mathrm{session}
\end{gathered}
$$

\section{Equation 3: Electricity Fee}

E-Electricity expense (\$/session)

K-Energy per Session (kWh)

$\mathrm{R}_{\mathrm{E}}-$ Price rate of electricity $(\$ / \mathrm{kWh})$

$$
\begin{gathered}
E=K \times R_{E} \\
E=3.3 k W h \times \$ 0.103 / k W h=\$ 0.34 / \text { session }
\end{gathered}
$$




\section{Equation 4: Network Fee}

$$
\begin{aligned}
& \mathrm{N}-\mathrm{Network} \text { expense (\$/session) } \\
& \mathrm{C}_{\mathrm{N}}-\text { Network contract (\$/year) } \\
& \mathrm{S}_{\mathrm{N}}-\text { Charge sessions in a year (sessions/year) } \\
& N=\frac{C_{N}}{S_{N}} \\
& N_{E 1}=\frac{\$ 0 / y r}{261 \text { sessions } / y r}=\$ 0.00 / \text { session } \quad N_{E 2}=\frac{\$ 280 / y r}{522 \text { sessions } / \text { year }}=\$ 0.54 / \text { session }
\end{aligned}
$$

\section{Equation 5: Unit Fee}

$$
\begin{aligned}
& \text { U-Installation expense (\$/session) } \\
& \mathrm{Cu}-\text { Cost of installation (\$) } \\
& \text { Au-Amortization period (years) } \\
& \mathrm{S}_{\mathrm{M}} \text {-Charge Sessions in a year (sessions/year) } \\
& U=\frac{\left(\frac{C_{U}}{A_{U}}\right)}{S_{M}} \\
& U_{E 1}=\frac{\left(\frac{\$ 100}{10 y r s}\right)}{261 \text { sessions } / y r}=\$ 0.04 / \text { session } \quad U_{E 2}=\frac{\left(\frac{\$ 7,000}{10 y r s}\right)}{1,044 \text { sessions } / y r}=\$ 0.67 / \text { session }
\end{aligned}
$$

\section{Equation 6: Install Fee}

$$
\begin{aligned}
& \text { I-Installation expense (\$/session) } \\
& \mathrm{C}_{\mathrm{l}-\text { Cost of installation }(\$)} \\
& \mathrm{Al}_{1} \text {-Amortization period (years) } \\
& \mathrm{S}_{\mathrm{M}-\text { Charge Sessions in each month (sessions } / \text { month) }} \\
& \qquad I=\frac{\left(\frac{C_{I}}{A_{I}}\right)}{S_{M}} \\
& I_{E 1}=\frac{\left(\frac{\$ 500}{40 y r s}\right)}{261 \text { sessions } / y r}=\$ 0.05 / \text { session } \quad I_{E 2}=\frac{\left(\frac{\$ 2,000}{40 y r s}\right)}{522 \text { sessions } / y r}=\$ 0.10 / \text { session }
\end{aligned}
$$


(This page intentionally left blank) 
ENERGY EFFICIENCY \&

RENEWABLE ENERGY 